\title{
T-Cell Proliferation
}

National Cancer Institute

\section{Source}

National Cancer Institute. T-Cell Proliferation. NCI Thesaurus. Code C19599.

An increase in the number of all, or specific subsets of, T-cells by cell growth and cell division during an immune response or during development. 